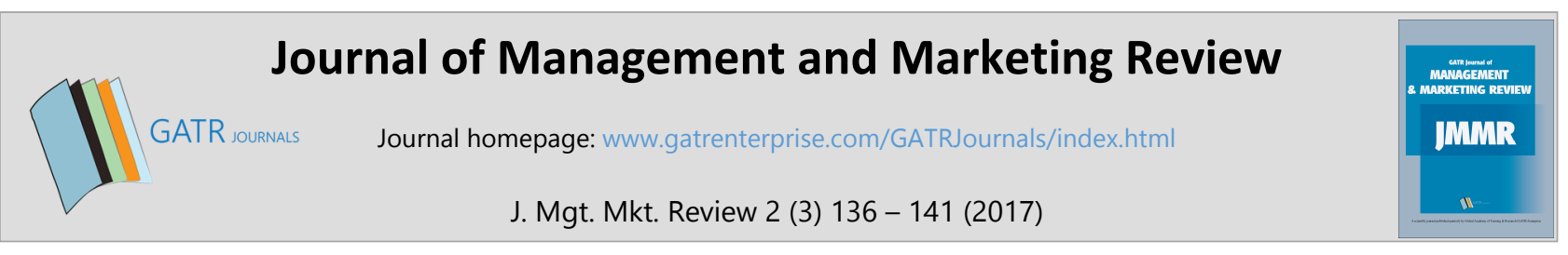

\title{
Happiness in Higher Education Leader
}

\author{
Ninik Setiyowati ${ }^{1 *}$ and Irtaji $^{2}$ \\ ${ }^{1,2}$ State University of Malang, Jalan Semarang 5, 65145, Malang, Indonesia
}

\begin{abstract}
Objective - This study examines Happiness Leaders in the higher education context.

Methodology/Technique - Using Positive Psychology perspective, data were collected through an in-depth interview with 30 Indonesian heads of Department in some faculties of Higher Education Malang from December 2016 to February 2017. Respondents were selected using non-probability purposive sampling technique.

Findings - The results of this study indicate that the respondents focused their happiness factor more on relationship (R) and meaningfulness (M), but less on positive emotion (P), engagement (E) and accomplishment (A). Almost all respondents agreed that good relationship ensured a sense of safety and comfort and helped gain social support, especially when they were in Bad Condition. Otherwise, most respondents tended to lack focus in setting targets and did not enjoy through the process of achieving the target. Responsibilities were exercised only to meet the demand of the institution.

Novelty - This research developed five aspects: positive emotion, engagement, relationship, meaningfulness and accomplishment (PERMA) as a key question and tested it in the context of Indonesia.
\end{abstract}

Type of Paper: Empirical.

Keywords: Happiness; PERMA; Qualitative; Positive Psychology.

JEL Classification: I21, J28, M54.

\section{Introduction}

Happiness in the workplace is crucial for improving productivity in any organization. Happy people are productive people, while those who are unhappy may not pay full attention to any task (Sharif \& Majid, 2015). Leaders have a crucial role in creating fun climate. For all situations, leaders are required to be effective in leading. But more than anything, Leader must be happy. Regardless of the model of leadership, either transformational, transactional, situational, exemplary or paradigm of positive leadership, they still need to focus on achieving their goals. The leaders' positive mood will not only directly enhance team performance, but also indirectly lead to improved team performance through the explicit mediating process in the context of transformational leadership practice and the implicit mediating process when practicing positive group affective tone (Chi, Chung, \& Tsai, 2011). The leaders' positive effect is positively related to leadership criteria, whereas leaders' negative effect is negatively related to leadership criteria.

Positive emotion results in the tendency to approach rather than to avoid and to prepare the individual to seek out and undertake new goals. Firstly, because happy people experience frequent positive moods, they

\footnotetext{
* Paper Info: Received: December 19, 2016

Accepted: June 22, 2017

* Corresponding author:

E-mail: ninik.setiyowati.fppsi@um.ac.id

Affiliation: Psychology Faculty, State University of Malang, Indonesia
} 
have a greater likelihood of working actively toward new goals while experiencing those moods. Secondly, happy people are in possession of past skills and resources, which they have built over time during previous pleasant moods (Lyubomirsky, King, \& Diener, 2005).

Happiness in the Positive Psychology in its earlier emergence known as Authentic Happiness consists of three dimensions, namely positive emotion, engagement and meaning (Seligman, Martin E. P., Csikszentmihalyi, \& Mihaly, 2000). However, the three dimensions experienced some improvement and perfection into the five pillars (PERMA) known as flourishing. People will have the feeling of well-being when they successfully achieve the objectives that they have set. If they are able to have these five pillars, they will feel prosperous (Seligman, 2002).

Tridharma Perguruan Tinggi, hereinafter referred to as Tridharma, is the obligation of a higher educational institution to organize education, research and service to the community. Research refers to an activity conducted following scientific principles and methods in a systematic manner and/or the test of a branch of science and technology. Service to the community refers to an activity of the society of academicians that utilize Sciences and Technology to promote the well-being of the community and to enrich the life of the nation. Learning refers to a process of interaction between students and lecturers as well as learning sources in a learning environment (Law of the Republic of Indonesia Number 12 of 2012). To be a leader of an educational institution, one must have the ability to handle people by fulfilling the three obligations above.

In an educational institution, a leader is responsible for matters related to the performance of a lecturer, learning and teaching process and policies within the environment of the society of academicians. In addition, in excercising the institutional responsibility in enabling the higher educational institution he or she leads to be able to functions well, a leader needs effective focus and consentration.

When getting extraordinary things done in organizations, leaders engage in these five practises of exemplary leadership : (1) model the way, (2) inspire a shared vission, (3) challenge the process, (4) enable others to act, and (5) encourage the heart (Kouzes \& Pozner, 2007). Black (2015) makes a comparison on leadership by referring to Kouzes and Pozner (2007) for higher education leadership. Astin A.W. and Astin H.S. (2000), in Black's summary, states that higher education leadership requires (1) Self-knowledge, Authenticity/integrity; (2) Shared Purpose, Competence; (3) A learning environment, Disagreement with respect; (4) Collaboration, Division of labour; (5) Commitment, Empathy/understanding of others.

\section{Material and Method}

Data were collected through an in-depth interview with 30 Indonesian heads of Department in some faculties of Higher Education Malang from December 2016 to February 2017. Respondents were selected using nonprobability purposive sampling technique.

The sample comprised 12 female leaders and 18 Male Leaders aged 45-55. The education level was postgraduate with at least 2 years of experience as leaders. Participants were recruited via door-to-door and online methods. After agreeing to become participants, researchers began to conduct the in-depth interview process.

The variation of participants being interviewed by the researcher is as follows: 
Table 1. Participant summary

\begin{tabular}{|l|l|l|}
\hline Positions & Number of Participants & \multicolumn{1}{|c|}{ Participant Uniqueness } \\
\hline Dean & 5 participants & $\begin{array}{l}\text { Leaders who have more than 40 subordinates varying } \\
\text { from dean to educators and mostly older than them. (D1, } \\
\text { D2,D3,D4,D5) }\end{array}$ \\
\hline Vice Dean & 2 participants & $\begin{array}{l}\text { Holding the position related to financial affairs. } \\
\text { (VD.1,VD.2) }\end{array}$ \\
\hline Head of Department & 12 participants & $\begin{array}{l}\text { Participants are involved as leaders after gaining } \\
\text { experience as staff members and supervisors (equivalent } \\
\text { to head of study program or secretary of department) } \\
\text { (HD.1, HD.2, HD.3, HD.4, HD.5, HD.6, HD.7,HD.8, } \\
\text { HD.9,HD.10,HD.11,HD.12) }\end{array}$ \\
\hline Head of Study Program & 8 participants & $\begin{array}{l}\text { Leaders of new study } \\
\text { (HS.1,HS2,HS3,HS4,HS5,HS6,HS7,HS8) }\end{array}$ \\
\hline Head of Office & 3 participants & $\begin{array}{l}\text { Participants have been active as leaders at the faculty } \\
\text { level, and they are promoted to the university level to } \\
\text { head Offices. (HO.1,HO.2, HO.3) }\end{array}$ \\
\hline
\end{tabular}

This research uses a list of questions as follows:

- How you feel when facing many challenges as a leader? Tell me the best experience that makes you feel overwhelmed by positive feelings?

- How you deal with the situation? How you feel the engagement with your work team and your work?

- How you build interpersonal relationships with your work team?

- What your leadership principle as a substantial believe that encourages your optimal leadership?

- What your best achievement that you attain? How do you make it happen?

- Tell me using one word that represents your basic principles in carrying out leadership functions in your educational institution

\section{Results}

There are 5 patterns in this research that have been successfully summarized by the researcher from 30 participants. The researcher found that there were 20 participants who had the same pattern, where they demonstrated high relationship and meaning but low positive emotion, engagement and accomplishment. This means that 66.67 percent of all participants showed this pattern. There were four participants who had high positive emotion, meaning and relationship and low engagement and accomplishment. In this research, only two participants showed strong behavior in all five aspects of happiness. Two other participants had high positive emotion and accomplishment but low engagement, relationship and meaning. In the last pattern, two participants showed adequate behavior in meaning and accomplishment but low in positive emotion, engagement and relationship.The following is the table that summarizes the results of this research.

Table 2. Summary of the happiness patterns of higher education leaders

\begin{tabular}{|l|c|c|c|c|c|c|}
\hline Pillars & $\begin{array}{c}\text { Positive } \\
\text { Emotion }\end{array}$ & Engaggement & Relationship & Meaning & Accomplishment & $\begin{array}{c}\text { Number of } \\
\text { Participants }\end{array}$ \\
\hline Pattern 1 & Low & Low & High & High & Low & 20 \\
\hline Pattern 2 & High & Low & High & Low & Low & 4 \\
\hline Pattern 3 & Low & Low & Low & High & high & 2 \\
\hline Pattern 4 & High & High & High & High & High & 2 \\
\hline Pattern 5 & High & Low & Low & Low & High & 2 \\
\hline
\end{tabular}


Table 3. Recap of the results of behaviors occurring in the participants

\begin{tabular}{|c|c|}
\hline Pillars & Summary of behaviors that occurred \\
\hline $\begin{array}{l}\text { Low } \\
\text { emotion }\end{array}$ & $\begin{array}{l}\text { The leader felt that they sacrificed and restricted their personal desires. He or she also } \\
\text { yielded and let others move forward. Furthermore, the leader stated that his or her } \\
\text { position was a burden. }\end{array}$ \\
\hline $\begin{array}{l}\text { High } \\
\text { emotion }\end{array}$ & $\begin{array}{l}\text { The leader showed appreciation, had altruism bahavior (helping others out of affection), } \\
\text { inspired, positioned him- or herself like the parents of his or her subordinates (ngemong) } \\
\text { and consistently motivated work progress. }\end{array}$ \\
\hline Low Engaggement & $\begin{array}{l}\text { The leader did his or her duties individually without involving his or her staff members, } \\
\text { the work was done strictly following the rules, and there was an emphasis that a leader } \\
\text { had control and supervision functions. }\end{array}$ \\
\hline High Engaggement & $\begin{array}{l}\text { The leader loved his or her work, was willing to take part in completing works, realized } \\
\text { that job was "amanah" or trust, which made him complete his or her duties optimally. }\end{array}$ \\
\hline Low Relationship & $\begin{array}{l}\text { The leader showed differences between him- or herself and s subordinates, which would } \\
\text { kept the existing gap. He or she expected him- or herself to play the role of a strict person } \\
\text { and to avoid any emotional engagement. His or her relationship with subordinates was } \\
\text { the realationship of teaching subordinates. He or she applied strict control and } \\
\text { supervision to his or her subordinates and followed the standard operating procedures. }\end{array}$ \\
\hline High Relationship & $\begin{array}{l}\text { Any conflict was settled together. The leader also implemented "urun rembug" (sharing } \\
\text { feedbacks) but did not openly made criticisms. The leader was considered by the team } \\
\text { member as a family member. He or she also had initiative to advice subordinates who } \\
\text { made mistakes. The leader involved the team in work and asked their opinions. He or she } \\
\text { gave access for them to participate in making the final decision and initiated socialization } \\
\text { on organization's vision. }\end{array}$ \\
\hline Low Meaning & $\begin{array}{l}\text { The leader worked following the rules and standards. The leader perceived work as a } \\
\text { responsibility although it might be hard. He or she realized that there would be some } \\
\text { consequences that he or she had to accept. One of the consequences would be being } \\
\text { ready to be opposed by some people. When failures occured, the leader bore them as } \\
\text { personal humiliating mistakes. }\end{array}$ \\
\hline High Meaning & $\begin{array}{l}\text { The leader realized that working is a form of service. Being a sincere leader was the the } \\
\text { most important thing. The leader exercised his or her responsibility with pleasure } \\
\text { becuase when leading, the role to develop the team became a calling. The leader showed } \\
\text { willingness to work hard at that time and was optimistic that the institution would } \\
\text { develop. The overall achievements gained by the institution would be great happiness. }\end{array}$ \\
\hline $\begin{array}{l}\text { Low } \\
\text { accomplishment }\end{array}$ & $\begin{array}{l}\text { The leader urged others to move forward and they would be happy for them. They did } \\
\text { not really pay attention to their personal achievements and they were less concrete in } \\
\text { formulating the target of their organizations. They would put the responsibility of } \\
\text { developing the organization on the younger generation. They would avoid, if not } \\
\text { eliminate, conflicts. Individual target achievements would be the second priority because } \\
\text { they would feel bad if they surpassed their seniors and they thought that they deserved } \\
\text { less than those younger than them. }\end{array}$ \\
\hline $\begin{array}{l}\text { High } \\
\text { Accomplishment }\end{array}$ & $\begin{array}{l}\text { They set targets to surpass previous leaders. They had the courage to make some } \\
\text { improvement on the existing condition and reorganize those that were not optimal. They } \\
\text { set clear, measured targets. They regularly conducted socialization and induction of } \\
\text { information to their subordinates. They were also ready to bear the risks if mistakes } \\
\text { occured or wrong decisions were made. }\end{array}$ \\
\hline
\end{tabular}




\section{Discussion}

Twenty leaders or 66.7 percent of all participants showed the same pattern, which was the behaviors that demonstrated meaning and relationship. The emphasis that position was a form of service and work team were brothers and sisters that deserved to be treated with affection was very apparent in each participant. In the characteristics of people with interdependence to each other, which stands out more in a more collective culture, emphasis lies in the relational values in orientation such as humility and the sense of ownership, and relational aspect is the main aspect of giving meaning to oneself and success (Gardner, Gabriel \& Lee, 1999; Triandis, McCusker \& Huis, 1990). This is obvious in the high level of relationship aspect prioritized by 26 participants.

Indonesia has diverse cultures which consist of more than 200 cultures, including Javanese culture, Sundanese culture, Batak culture and some other cultures (Suseno, 1996). Despite the large number of cultures in Indonesia, there are some dominant values that are accepted and applied, either in the attitude or behavior, by the majority of Indonesian people. Those values include: harmony, tolerance, mutual cooperation and religious value. Harmony and tolerance refer to the act of maintaining balance in the society (Sarwono, 1998). This was apparent in the responses of participants when they were asked about Accomplishment. The leaders' ambition to achieve something was not expressed straightforwardly. It was expressed indirectly in order to avoid open conflicts. Meanwhile, mutual cooperation is the value adhered by the Indonesian nation. This clearly indicates that relationship has always been the main point in the the occupational relationship. Harmony, tollerance and mutual cooperation are also known as a collective culture or "us" culture (Hofstede, 1994). This is also supported by some studies stating that Eastern cultures put emphasis on interpersonal comparisons. While Euro-American cultures emphasize freedom and independence, Eastern cultures focus on harmony and collective (Ye, Ng, \& Lian, 2015).

In previous studies, especially in collectivism cultures, happiness tends to be defined as a positive feeling contingent upon social engagement (e.g., interpersonal harmony, family well-being, or connectedness). Accordingly, a person who is motivated to pursue happiness in East Asia may find it more appropriate and be more encouraged by their culture to seek happiness through social engagement. (Ford et al., 2015)

Higher education leaders have a responsibility to fulfill the tridharma perguruan tinggi: teaching, research and service to the community. The three important things aformentioned emphasizes some aspects. Teaching, in addition to the field of science, is also closely related to building relations with students. Service to the community and research also require intense relations with others and involve interpersonal and communication skills. Higher education leaders mainly emphasize the aspects of empathy and understanding of others (Astin A.W. and Astin H.S., 2000). Bryman (2007) explains that leaders must also have the following behaviors: Acting as a role model and having credibility, being considerate, treating academic staff fairly and with integrity, being trustworthy and having personal integrity. The empathy for all socity of academicians and being a person with integrity are the responsibility and something that will give significant meaning for a higher education leader. A good relationship with others, which may create a harmoneous working atmosphere, will enable leaders to better enjoy their jobs without feeling burdened.

\section{Conclusion}

A higher education leader has some distinctive characteristics of responsibility. In addition to the role of leading a working team, he or she must also be responsible for teaching, research and service to the community. The aspects of meaning and relationship in PERMA were highly apparent in the participants. Empathetic behavior, building good relationship and showing harmonious communication make leaders feel better wellbeing psychologically in between challenging tasks. Besides, by giving meaning to work as a service and realizing that the work will have an implication on others and all society of academicians, a leader can be more optimistic in viewing his or her work. 
The most dominant PERMA pillars are meaning and relationship. This is due to the collective nature of Indonesian nation's culture. Collective culture emphasizes harmony with others. Social engagement in the forms of personal harmony with work team, the feeling of being part of a family and connected with the team become very important.

\section{Acknowledgements}

The accomplishment of this reseach benefits of the help and direction from my Dean-Prof. Fattah Hanurawan, M.Si, M.Ed who willing to help me solve the confusions and administration problem. I would like to express my sincere appreciation and gratittude to Prof. Budi Eko Soetjipto, M.Ed, M.Si as an easy-going and open-minded person, whom is also a good friend to me. Without his encouragement, I would not finish this research. I am also grateful to all the participants who helped me take the data in their busy schedule.

\section{References}

Astin, A. W., \& Astin, H. S. (2000). Leadership Reconsidered: Engaging Higher Education in Social Change. Battle Creek, MI: W.K. Kellogg Foundation.

Black, S. A. (2015). Qualities of effective leadership in higher education. Open Journal of Leadership, 4(02), 54-66. http://dx.doi.org/10.4236/oj1.2015.42006

Bryman, A. (2007). Effective leadership in higher education: A literature review. Studies in higher education, 32(6), 693710. http://www.tandfonline.com/ http://dx.doi.org/10.1080/03075070701685114

CHI, N. W., CHUNG, Y. Y., \& TSAI, W. C. (2011). How do happy leaders enhance team success? The mediating roles of transformational leadership, group affective tone, and team processes. Journal of Applied Social Psychology, 41(6), 1421-1454.

Ford, B. Q., Dmitrieva, J. O., Heller, D., Chentsova-Dutton, Y., Grossmann, I., Tamir, M., ... \& Bokhan, T. (2015). Culture shapes whether the pursuit of happiness predicts higher or lower well-being. Journal of Experimental Psychology: General, 144(6), 1053.

Gardner, W. L., Gabriel, S., \& Lee, A. Y. (1999). "I" value freedom, but "we" value relationships: Self-construal priming mirrors cultural differences in judgment. Psychological Science, 10(4), 321-326.

Hofstede, G. (1994). Cultures and organizations: software of the mind. London: Harper-Collins Publishers.

Kouzes, J. M., \& Posner, B. Z. (2007). The Leadership Challenge. San Francisco, CA: Jossey-Bass Publishers.

Lyubomirsky, S., King, L., \& Diener, E. (2005). The Benefits of Frequent Positive Affect: Does Happiness Lead to Success?. Psychological Bulletin, 131(6), 803-855

Sarwono, S. S. (1998). Cultural values and marketing practices in Indonesia. Jurnal Ekonomi dan Bisnis Indonesia, 13(2), 90-100

Seligman, Martin E. P., Csikszentmihalyi, \& Mihaly. (2000). Positive Psychology: An Introduction. American Psychologist, 55(1), 5-14. http://dx.doi.org/10.1037/0003-066X.55.1.5

Seligman, M. E. P. (2002). Authentic Happiness: Using the New Positive Psychology to Realize Your Potential for Lasting Fulfillment. Cognitive Behavioral Therapy Book Reviews, 1(8).

Sharif, M. Y., \& Majid, A. H. A. (2014). A conceptual framework of happiness at the workplace. Asian Social Science, 11(2), 78.

Triandis, H. C., McCusker, C., \& Huis, C. H. (1990). Multimethod probes of individualism and collectivism. Journal of Personality and Social Psychology, 59, 1006-1020.

UURI (2012). Undang-undang Republik Indonesia Nomor 12 TAHUN 2012. Retrieved from https://portal.mahkamahkonstitusi.go.id/eLaw/mg58ufsc89hrsg/1f32ffaa83555e001038d1e0cda7b281849acef2d. pdf di unduh 28 maret 2017

Ye, D., Ng, Y. K., \& Lian, Y. (2015). Culture and happiness. Social indicators research, 123(2), 519-547. DOI $10.1007 / \mathrm{s} 11205-014-0747-\mathrm{y}$ 